\title{
Relation Between Body Composition and Motor Abilities of Children up to 7 Years of Age
}

\author{
Relación entre Composición Corporal y Habilidades Motoras en Niños de hasta 7 Años de Edad
}

\author{
Josip Lepes*; Sabolc Halasi*; Sanja Mandaric ${ }^{* *}$ \& Nada Tanovic ${ }^{* *}$
}

LEPES, J.; HALASI, S.; MANDARIC, S. \& TANOVIC, N. Relation between body composition and motor abilities by children of up to 7 years of age. Int. J. Morphol., 32(4):1179-1183, 2014.

SUMMARY: In a sample of 125 respondents, 62 boys and 63 girls, who attended the first grade of primary schools in Subotica with average age of 7.39 decimal years, a measurement of basic anthropometric characteristics was performed, general motor skills were determined based on seven motor tests, and body composition was determined using the In Body 230 device. Regression analysis showed that the predictor system of variables for assessing body composition (amount of body fat, the total amount of water and the total amount of muscles) was statistically significantly associated with the criterion defined as general motor factor and with it describes $39 \%$ of common variability in boys $(\mathrm{R}=0.63 ; \mathrm{p}<0.05)$ and $34 \%$ in girls $(\mathrm{R}=0.58 ; \mathrm{p}<0.05)$. Standardized regression coefficient indicated that both for boys and girls aged 7.39 decimal years, statistically, the total amount of body fat, body weight, negatively affect general motor skills and for the girls, statistically, body height has a positive effect.

KEY WORDS: General motor skills; Body composition; Primary school.

\section{INTRODUCTION}

Motor skills of children, youth and people are affected by different structural features that define them as a biopsycho-social-integrated being. In order to achieve allaround development of motor skills potential, it is necessary to know the elements which we can change, and which are crucial for the implementation of kinesiology activities.

In this paper a tendency is imposed to view motor status of the child in a comprehensive and complete manner, because the motor skills are still not differentiated, but have the general character (Nicin 2000; Sekulic \& Metikos, 2007; Matic, 2008).

Previous research (Matic, 2006; Turek, 2006) discovered significant effect of biological development, and anthropometric characteristics on the performance of motor tests in young school children.

The human body is complex composed of many tissues that change as the body develops, matures and gets old. Human characteristics, abilities and constitution are constantly changing in a relatively steady manner, consistent with the known laws of physical development.
The aim of this study was to determine the influence of anthropometric characteristics and body composition on motor abilities of first-graders boys and girls in Subotica.

\section{MATERIAL AND METHOD}

The research method had a transverse character. All measurements and tests were conducted on a sample of 125 respondents from Subotica, from two schools "Majsanski put" and "J. J. Zmaj". All boys $(n=62)$ and girls $(n=63)$ were first-graders (Mean=7.39; $\mathrm{SD}=0.44)$, and three times a week, attended physical education classes together, held by separate teachers for each class during the whole school year, with the applied exercise program on those classes.

As a sample of measuring instruments for the purposes of study, the following anthropometric characteristics were selected:

1.- Body height $(\mathrm{cm})$ - was measured using anthropometry according to Martin and,

\footnotetext{
* University of Novi Sad, Teachers' Training Faculty in Hungarian, Subotica, Serbia.

${ }^{* *}$ University of Belgrade, Faculty of Sport and Physical Education, Belgrade, Serbia.
} 
2.- Body weight $(0.1 \mathrm{~kg})$ - was measured using InBody 230 (Biospace Co., Ltd, Seoul, Korea),

3.- Body composition was assessed using use the InBody 230 device (Biospace Co., Ltd., Seoul, Korea),

4.- The total amount of body fat $(0.1 \mathrm{~kg})$,

5.- The total amount of water $(0.1 \mathrm{~kg})$,

6.- The total amount of muscles $(0.1 \mathrm{~kg})$.

For assessing anthropometrics in young school children, standard motor tests were used (according to the model of Bala et al. (2007)), and the following battery of tests was applied:

1.- To assess the factors of movement structuring:

- Reorganization of stereotypes of motion: 1 ) obstacle course backwards $(0.1 \mathrm{~s})$,

- Coordination of the whole body: 2) standing broad jump $(\mathrm{cm}), 3)$, running speed, 20 meter dash with a standing start (0.1 s),

2.- To assess the functional synergy of factors and regulation of tone:

- Frequency rate: 4) hand tapping (freq.),

- Flexibility: 5) seated straddle stretch (cm),

3.- To assess the factor of duration of the motor units excitation:

- Repetitive strength of the trunk: 6) Sit-ups in 60 s (freq.), - Static strength of the arms and shoulders: 7) Bent arm hang (hanging pull-ups) (0.1 s).

\section{RESULTS}

Based on the results of the t-test it can be concluded that there are significant differences between boys and girls in the motor variables $20 \mathrm{~m}$ dash with a standing start $(\mathrm{p}<0.00)$, Obstacle course backwards $(\mathrm{p}<0.00)$ and Standing broad jump $(p<0.00)$ in favor of boys and variables Seated straddle stretch $(\mathrm{p}<0.00)$ in favor of girls (Table I).

The boys had better and statistically significant average results, compared to the subsample of girls of the same age, in terms of the variables for assessing body composition, namely, Total amount of muscles and total amount of water in the body (Table I). This greater muscle volume in favor of boys had an impact on better motor skills (listed above) that reflected in motor tests of the strength, speed and coordination. Age-related changes in Total amount of fat mass are generally considered to become manifest after puberty in boys and girls. While boys and girls have similar avarage stature, body mass, and BMI before puberty (Siervogel et al., 1991).

It can be observed (Table II) that variables for assessing the coordination in boys, which are influenced by factor of the movement structuring, best describe the common variance with the general motor factor. Children's motor skills in this case are mostly defined by mechanisms of reorganization of movement stereotypes and the factors of duration of the motor units excitation manifested by va-

Table I. Differences in the studied anthropometric, motor and body composition variables, among respondents of different sexes.

\begin{tabular}{|c|c|c|c|c|c|c|}
\hline \multirow{2}{*}{ Variable } & \multicolumn{2}{|c|}{ Girls $(n=63)$} & \multicolumn{2}{|c|}{ Boys $(n=62)$} & \multirow[b]{2}{*}{$\mathbf{t}$} & \multirow[b]{2}{*}{$\mathbf{p}$} \\
\hline & Mean & SD & Mean & SD & & \\
\hline Body height $(\mathrm{cm})$ & 130.52 & 6.51 & 130.96 & 6.57 & 0.38 & 0.71 \\
\hline Body weight $(0.1 \mathrm{~kg})$ & 28.02 & 6.91 & 29.01 & 6.89 & 0.80 & 0.43 \\
\hline $20 \mathrm{~m}$ dash with a standing start $(0.1 \mathrm{~s})$ & 49.79 & 5.65 & 45.85 & 4.26 & $-4.40 *$ & 0.00 \\
\hline Obstacle course backwards (0.1 s) & 262.43 & 101.73 & 208.47 & 60.23 & $-3.62 *$ & $\mathbf{0 . 0 0}$ \\
\hline Seated straddle stretch $(\mathrm{cm})$ & 41.49 & 7.16 & 35.84 & 6.73 & $-4.55 *$ & $\mathbf{0 . 0 0}$ \\
\hline Bent-arm hang (0.1 s) & 111.25 & 98.85 & 119.52 & 95.84 & 0.47 & 0.64 \\
\hline Hand tapping (freq.) & 22.03 & 3.39 & 22.63 & 3.86 & 0.92 & 0.36 \\
\hline Sit-ups in $60 \mathrm{~s}$ (freq.) & 25.94 & 6.30 & 27.48 & 7.26 & 1.27 & 0.21 \\
\hline Standing broad jump $(\mathrm{cm})$ & 124.52 & 17.85 & 137.94 & 15.84 & $4.41 *$ & 0.00 \\
\hline Total amount of muscles $(0.1 \mathrm{~kg})$ & 11.04 & 2.05 & 11.95 & 2.02 & $2.51 *$ & 0.01 \\
\hline Total amount of body fat $(0.1 \mathrm{~kg})$ & 5.84 & 4.29 & 5.44 & 4.44 & -0.51 & 0.61 \\
\hline Total amount of water $(0.1 \mathrm{~kg})$ & 16.31 & 2.50 & 17.34 & 2.50 & $2.31 *$ & 0.02 \\
\hline
\end{tabular}

Mean = arithmetic mean; $\mathrm{SD}=$ standard deviation; $\mathrm{t}=\mathrm{t}$-test value; $\mathrm{p}=$ statistical significance level for $\mathrm{t}$-test. 
riable Sit-ups from lying on back and Bent-arm hang. In girls it can be seen that the common variances with the general motor factor are described the best by the variables for the assessment of coordination, which are influenced by factor of the movement structuring.

Results of regression analysis of general motor factor in boys and girls (Table III) indicated a statistically significant $(\mathrm{P}<0.00)$ impact of predictor system of variables (variables of body composition and basic anthropometric variables) on the criterion variable General motor factor in children aged 7 years with the multiple correlation coefficient value of $\mathrm{R}=0.63$ for boys and $\mathrm{R}=0.58$ for girls. Predictor system of variables explained 39\% of common variability with the criterion for boys and somewhat less, $34 \%$ for girls.

Table II. The structure of the main component.

\begin{tabular}{lcc}
\hline \multicolumn{1}{c}{ Variable } & Boys & Girls \\
\hline Standing broad jump & 0.806 & 0.705 \\
Sit-ups in 60 s & 0.779 & 0.670 \\
20 m dash with a standing start & -0.737 & -0.767 \\
Obstacle course backward & -0.662 & -0.801 \\
Bent-arm hang & 0.586 & 0.458 \\
Seated straddle stretch & 0.479 & 0.574 \\
Hand tapping & -0.144 & 0.451 \\
\hline \% of common variance & 40.44 & 41.681 \\
\hline
\end{tabular}

Table III. Results of regression analysis of the General motor factor in boys and girls.

\begin{tabular}{lcccccccc}
\hline \multirow{2}{*}{ Variable } & \multicolumn{4}{c}{ Boys } & \multicolumn{6}{c}{ Girls } \\
\cline { 2 - 10 } & $\mathbf{r}$ & $\mathbf{p}$ & Beta & pbeta & $\mathbf{r}$ & $\mathbf{p}$ & Beta & pbeta \\
\hline Body height & $-0.25^{*}$ & 0.05 & 0.21 & 0.23 & 0.07 & 0.60 & $0.44^{*}$ & 0.00 \\
Body weight & $-0.45^{*}$ & 0.00 & - & 0.00 & $-0.30^{*}$ & 0.02 & $-0.58^{*}$ & 0.00 \\
Total amount of & -0.14 & 0.27 & 2.70 & 0.07 & -0.02 & 0.86 & 0.24 & 0.35 \\
Total amount of body & $-0.57^{*}$ & 0.00 & - & 0.00 & $-0.47^{*}$ & 0.00 & $-0.73^{*}$ & 0.00 \\
Total amount of water & -0.17 & 0.20 & -2.51 & 0.09 & 0.00 & 0.99 & 0.20 & 0.42 \\
$\mathrm{R}$ & \multicolumn{4}{c}{$0.63^{*}$} & & & $0.58^{*}$ & \\
$\mathrm{R}^{2}$ & \multicolumn{4}{c}{0.39} & & & 0.34 \\
$\mathrm{P}$ & \multicolumn{4}{c}{0.00} & \multicolumn{4}{c}{0.00} \\
$\mathrm{r}=$ Pearson's correlation coefficient; $\mathrm{p}=$ level of statistical significance for r; Beta= regression \\
coefficient; pbeta= significance level of the regression coefficient; $\mathrm{R}=$ multiple correlation coefficient; \\
$\mathrm{R}^{2}=$ determination coefficient; $\mathrm{P}=$ significance of the multiple correlation coefficient.
\end{tabular}

\section{DISCUSSION}

The standardized regression coefficient (Beta) shows that for both boys and girls aged 7 the general motor skills are statistically significantly influenced by Total amount of body fat, Body weight, and for girls even Body height. Obtained results, reflected in the negative impact of the Total amount of body fat on the efficiency of the motor tasks execution, are expected. Children with an increased amount of fat achieved poorer results in motor tests, which they were asked to perform. Body fat is the ballast material that makes it difficult to perform strength tests (Bent-arm hang, Sit-ups in $60 \mathrm{~s}$ ). It is also negatively correlated with all forms of strength (Szakály, 2008; Raustorp et al., 2004). These results partially support the negative impact of subcutaneous adipose tissue on the results of the tests for the assessment of coordination Obstacle course backwards, Standing broad jump and Bent-arm hang, referred to by Matic (2008) and hence confirm one part of his research. Therefore, the results of this research confirm some of his research. Also, this study confirms the results of research by Jozic \& Hrzenjak (2006) who in their study confirmed that there is a statistically significant correlation and the impact of subcutaneous adipose fat on general motor factor in children.

High level of body fat and certain lifestyle (of sedentary nature, with reduced physical activity of today's youth and children) justifies and confirms the negative impact of total amount of Body fat on General motor factor both in boys and girls. The association between motor coordination and body fat further supports the hypothesis that low level of motor coordination may be a risk factor for obesity in children (Cairney et al., 2011). The amount of body fat decreases linearly the results of physical abilities even in children with normal body composition (Raustorp et al.). Children who are overweight before age 8 are likely to have more severe obesity as adults (Freedman et al., 2001). The causes of this should be sought in the last 10-15 years, lifestyle changes, reduced levels of physical activity and a greater amount of energy intake (Szakály). Both in 
industrialized societies and in the developing world there is a common trend of body fat increase (Szakály). Obesity epidemic has been recognized, significant attention has been focused on ways to prevent weight problems among children. Although genetics may play a substantial role in many cases of obesity, much can be done in the way of prevention by changing individual behaviors of increasing physical activity, decreasing sedentary behavior, and improving dietary habits (Steele et al., 2008).

The positive effect of Body height on General motor factor in girls may be explained by a faster maturation of girls, because the Body height variable is used to assess the growth and development of the child's organism, and the higher they were, the "more mature" they were, the impulses flow towards muscles is faster and also from the muscles to the CNS, so the results of the general motor behavior were better. Anthropometrical parameters at the same chronological and biological age of children are very different. There are differences between boys and girls in prepubertal ages. In the tests requiring speed and strength, the motor abilities in children with small statures test lower than children with normal or high statures. In contrast, the results of the tests that need endurance are relatively low in children who are very tall and have a high body mass (Nielsen et al., 2007; Docherty \& Gaul, 1991). This work could provide a contribution to the anthropological disciplines such as biological anthropology and anthropomotorics, and would be reflected in the analysis of state of particular anthropometric dimensions of the children from the area of Subotica, who are not included in the exercise program. It is possible to make an early selection of boys and girls for certain sports, as well as determining the structure of the morphological characteristics, motor skills and cognitive abilities of a specific population, such as young boys and girls of school age and their similarities and differences compared to the models of structure of above mentioned anthropological sub-spaces obtained in previous studies.

LEPES, J.; HALASI, S.; MANDARIC, S. \& TANOVIC, N. Relación entre composición corporal y habilidades motoras en niños de hasta 7 años de edad. Int. J. Morphol., 32(4):1179-1183, 2014.

RESUMEN: Se realizó la medición de las características antropométricas básicas y habilidades motoras generales en una muestra de 62 niños y 63 niñas, con una edad promedio de 7,39 años, de primer año de escuelas primarias en Subotica. Las características se determinaron en base de siete pruebas motoras, además de la composición corporal que se determinó utilizando el dispositivo In Body 230. El análisis de regresión mostró que el sistema predictor de las variables para evaluar composición corporal (cantidad de grasa corporal, cantidad total de agua y cantidad total de músculos) se asoció con el criterio definido como factor motor en general de manera estadísticamente significativa, y con ella se describió un 39\% de variabilidad común en los niños $(\mathrm{R}=0,63$, p<0,05) y en el 34\% de las niñas $(R=0,58, p<0,05)$. El coeficiente de regresión estandarizado indicó que tanto para niños y niñas de 7,39 años, la cantidad total de grasa y peso corporal afectan negativamente las habilidades motrices generales y para las niñas, la altura del cuerpo tiene un efecto estadísticamente positivo.

PALABRAS CLAVE: Habilidades motoras generales; Composición corporal; Escuela primaria.

\section{REFERENCES}

Bala, G.; Stojanovic, M. V. \& Stojanovic, M. The measurement and definition of motor skills in children. Novi Sad, Faculty of Sport and Physical Education, 2007.

Cairney, J.; Hay, J.; Veldhuizen, S. \& Faught, B. Assessment of body composition using whole body air-displacement plethysmography in children with and without developmental coordination disorder. Res. Dev. Disabil., 32(2):830-5, 2011.

Docherty, D. \& Gaul, C. A. Relationship of body size, physique, and composition to physical performance in young boys and girls. Int. J. Sports. Med., 12(6):525-32, 1991.

Freedman, D. S.; Khan, L. K.; Dietz, W. H.; Srinivasan, S. R. \& Berenson, G. S. Relationship of childhood obesity to coronary heart disease risk factors in adulthood: the Bogalusa Heart Study. Pediatrics, 108(3):712-8, 2001.
Jozic, M. \& Hrzenjak, M. Relationships between morphological characteristics and motor skills of fifth and seventh graders. In: Findak, V. (Ed.). Proceedings of the quality of work in the fields of education, sports and recreation. Rovinj, Croatian Kinesiology Association, 2006. pp.144-50.

Matic, R. Relations of motor skills, morphological and socioeconomic characteristics in children of early school age. MSc Thesis. Novi Sad, Faculty of Sport and Physical Education, 2008.

Matic, R. The influence of anthropometric characteristics to performance of motor tests in boys and girls of early primary school age. In: Bala, G. (Ed.). Anthropological status and physical activity of children and adolescents. Novi Sad, Faculty of Sport and Physical Education, 2006. pp.149-54. 
Nicin, D. Anthropomotorics-theory. Novi Sad, Faculty of Physical Education, 2000.

Nielsen, B. M.; Dencker, M.; Ward, L.; Linden, C.; Thorsson, O.; Karlsson, M. K. \& Heitmann, B. L. Prediction of fat-free body mass from bioelectrical impedance among 9- to 11-year-old Swedish children. Diabetes Obes. Metab., 9(4):521-39, 2007.

Raustorp, A.; Pangrazi, R. P. \& Stahle, A. Physical activity level and body mass index among schoolchildren in south-eastern Sweden. Acta Paediatr., 93(3):400-4, 2004.

Sekulic, D. \& Metikos, D. Basics of transformation processes in kinesiology. Split, Faculty of Natural Sciences, Mathematics and Kinesiology, 2007.

Siervogel, R. M.; Roche, A. F.; Guo, S. M.; Mukherjee, D. \& Chumlea, W. C. Patterns of change in weight/stature 2 from 2 to 18 years: findings from long-term serial data for children in the Fels longitudinal growth study. Int. J. Obes., 15(7):47985,1991 .

Steele, R. G.; Nelson, T. D. \& Jelalian, E. Pediatric Obesity: Trends and Epidemiology. In: Jelalian, E. \& Steele, R. G. (Eds.). Handbook of Childhood and Adolescent Obesity. New York, Springer, 2008. pp.3-10.

Szakály, Zs. Study of physique, body composition and motor performance characteristics. Ph.D. Thesis, Budapest, Semmelweis University, 2008.

Turek, M. Somatic development and movement ability in children of early school age. In: Bala, G. (Ed.), Proceedings of effects of differentiated physical education on psychosomatic status of children and youth. Novi Sad, Faculty of Physical Education, 2006. pp.465-88.

\section{Correspondence to: \\ Dr. Josip Lepes \\ University of Novi Sad \\ TeachersTraining Faculty in Hungarian \\ Strossmayer str. 11, 24000, Subotica \\ SERBIA}

Email: lepes@tippnet.rs

Received: 06-01-2014

Accepted: 28-05-2014 